\title{
Keyboard Action End up Political Party: Understanding the Intertwining Relations of Social Media Activism, Citizenship, and the Dynamics of Democracy in Indonesia Desideria Cempaka Wijaya Murti, Colorado State University, USA.
}

\begin{abstract}
The networked citizen-centered perspectives generate opportunities for the democratic innovations through self-actualized networking and interaction. A qualitative case study from Indonesia is used to examine the dynamics of citizenship participation in political discourse through social media. The movement started from public advocacy by clicking the 'like' button of Facebook Group to support marginalized individual then the movement evolved into provincial social activism. The Facebook connectivity help the group to build a political party to further back up their main figure in the forecast Presidential candidacy. Archival analysis of Facebook members postings message revealed five categories of Facebook role in facilitating democracy: public defense, political support, presidential allegiance, creative manufacturing, and counter disturbia. Using Breese's (2011) quadrant in public spheres continuum, the research illustrated that the movements evolve from 'click' action to 'real' action and develop from civic sphere to the political sphere. The research suggests that citizen participation in conversational politic sphere will face potential challenge in developing country context and security issue.
\end{abstract}

Keywords: political communication, social media, citizenship, social movement, democracy, Indonesia 


\section{Introduction}

Internet appears to be a powerful tool to decentralize information and message dissemination. Traditional media limit the ability of each individual to express opinion, only those who have power in media, able to disseminate message, create hegemonic information through propaganda and control (Negroponte, 1996). However, according to Dahlberg (2001), Internet has powerful ability to set the "online interactive public sphere" (Para. 5).

Indonesia is the contextual reference topic in this paper. It provides a country case especially on its receptive culture to online socialization (Pringle, 2011). Indonesia reveals us fascinating development of social media usage. Even though, World Bank (2011) still indicates Indonesia as a "Lower Middle Income Country," the numbers of Facebook users in Indonesia have reached the top two in the world after the United States. There are approximately 40,515,180 Indonesian Facebook users (Jakarta Globe, 2010). In other words, 16.68 (\%) of Indonesia's total population are on Facebook (Socialbakers, 2011).

More specifically, this study is a response to develop Bennett's concern in citizenship concept (2010): "This theory-driven framework offers a useful starting point for thinking about how to identify and understand different implicit organizational models of citizenship as they are communicated through civic learning and engagement features on Web sites" (p. 851). Combine with Bennett's concern, this study also an application of Breese's (2011) argument to see publics' activity in patterned ways. Breese says, "Understanding that public spheres vary in patterned ways - by scale or level and by orientation or mission - enables theorists and activists to reflect on and evaluate publics in new ways" (p. 146). Using different country context, the study is expected to demonstrate a theoretical application, find the pattern of social media use in politic and civic participation, and archive the political conversation as an appreciation towards democratic growth in relatively novel democratic country.

The movements, as the major attention in this paper, started from keyboards action by clicking the 'like' button of Facebook Group to support a political figure who is perceived by the members of Facebook group as a marginalized figure in the Indonesian political arena. The Facebook action then developed into provincial social activism, which aimed at engaging more people in political education mainly with the combination of Facebook activism and real action. Next, this group decided to build political party 
to support their main figure in the forecast Presidential candidacy in 2014. The movement engage citizen in political discourse through conversational sphere, allow the growth of both self-actualized and dutiful citizenship, expand the dynamics of public spheres, and also empower the role of Facebook as communication infrastructure. However, the movement also illustrates the challenge in 'keyboards' activism or 'keyboardism' related to the manifestation in real actions, decreasing commitment membership in the evolution process, and disturbance factors in the internal Facebook groups.

The paper presents a qualitative case study and divides in four sections. First of all, the paper presents the idea of democratic participation in the context of citizenship. Second, I review the pro and cons of democratic practice in social media, which encourage the democracy in social media but shows potential challenge in the same time. Third, I focus on scrutinizing the social movement in Indonesia by mapping the movements using Bresse's (2011) public spheres continuum. Four, I examine the archival conversations on Facebook as the artifacts of the movement, to understand the role of social media in the movement evolution. Here, I collect the conversations into five categories of Facebook role to facilitate the public discourse and political participation. Finally, I discuss the movement development with the concept of citizenship and media usage. I argue that the movement, which evolved from 'keyboards' action to 'real' action and developed from civic sphere to the political sphere, will face potential challenge.

\section{Literature Review}

Internet empowers people to engage in political participation. Social media also can create public advocacy for certain issues using discussion, organization, and mobilization (Kann et al, 2007). Samuel (2007) argued that public advocacy is perceived as a "value-driven political process" (p. 616) because the public wants to inquire and change inequality in the issue of power relations. It means that individuals engage in public/political issues outside them. Therefore, the public notices the existence of marginalized groups of people or individuals. Samuel (2007) also identified that public advocacy can also have power through networking alliance and solidarity.

Therefore, political discussion, public advocacy, and other political participation can be included as the engagement of citizen to develop the democratic participation. Ward (2011, 
look also Bennet, 2008) argued that the improvement of technology and accessibility to participate in digital media also develop the concept of citizenship. Citizen who participates in existing democratic engagement such as voting, engaging in political parties, representing community as leaders or senator, and attending public deliberation can be included as conventional citizenship or DC the dutiful citizen (Ward, 2011; Bennet, 2008). While citizen who involves in politic through digital media included as AC or Self-Actualized Citizenship. AC refers to members of groups who create personal bounds with peer networks, organize civic action using social technologies, and transfer the expression of individual through individual content production (Bennett, 2008). The development idea of citizenship, also congruent with Dahlgren's concept (2005) on the political socialization of individual, where through social media space, individual can come together and discuss civic issue. Thus, the social media enables individual to achieve their 'right to communicate' (Dakroury\&Birdsall, 2008).

Concerning the case of information content and dissemination; several experts delineate further arguments. McCombs (2004) argued that Facebook Groups might receive similar topics and themes in conventional media as a result of agenda setting. However, Wooley (2010) also argued that alternatively, Facebook could be used to counter those dominant discourses, especially on the issues in the election of presidential candidates. Tanis and Postmes (2003, see also Wooley et al, 2010) also put up that Facebook groups enable individuals to present the wide variety of information about their provision or displeasure for a cause, issue, or candidate. Gibson et al (2003) pointed out that websites for political campaign have various functions such as informative, interactivity, and discussion. Xenos and Foot's (2008) proposed the concept of co-productive interactivity works which enable users to comment on stories, blog, link, and allow them to leave feedback (see also Young, 2000). Norris (2003) highlighted it as 'interactive linkage between citizens and parties' (p.23).

However, the pessimistic argumentations also appeared as a result of the blossoming democracy through social media. The optimistic wave which glorify the use of digital media, tend to have challenge to non-internet users public (Norris, 2001), practical manipulation in political campaign, and thus; internet sometimes become a 'counterproductive infrastructure' in democracy. Other disadvantages of Internet is it can be potentially used for negative 
campaign, encourage populist or extremist rhetoric, and create digital celebrity politics for those who can master the Internet (Coleman\&Blumer, 2009). Meikle (2002) and Loader (2011) also questioned the comparison of commitment between the 'keyboard activism' and real actions that demand a higher commitment. Kavanaugh et al (2005) argued that the Internet has a 'weak-tie instrument' or less sustainable because it is also easy for a large number of people to join a digital group. In a popular term is digital bonding is 'easy come easy go'. Earl and Shussman (2003) also pointed out that 'members' tend to be 'users', who choose to disengage permanently after the action they support chose to develop. Even more, some scholars also became pessimist on the issue of trust and sustainability on the network of activist (Diani 2000; Clark \& Themudo 2003), because of the disparity motivation in driving public to engage on 'real' action and 'virtual' action.

\section{Research Design and Mapping the Movement}

I adopt the concept of mapping the movement to understand the examination of these social movements within their different approaches and tensions. Breese (2011) offered a system of mapping various public spheres and placed them along two axes, scale and content. She argued that public spheres stringed vertically (y axis) from face to face interaction to symbolic or mediated public sphere. Breese explained that 'face to face' interaction is communicating and acting collectively with other people in real time, while symbolic is interaction assisted by the media. For horizontal line (x axis), she argues that the public spheres range from political (which go exceedingly to state sphere), to civic public spheres (which go exceedingly to the pole of the private sphere).

Breese (2011) argued that constructing a typology may clarify how scholarly traditions conceptualize the public sphere and use mapping to discuss the public sphere and movement will help to understand "the incarnation of movement in contemporary social world" (p. 133). Using the mapping of the public sphere will help me to indicate "the interconnectedness, and the relevant divergences, of what have been considered distinct objects of study and forms of social interaction and action" (p. 133). 
Graphic. 1.1. Breese (2011) Map on Public Spheres

Face to face (x)

\begin{tabular}{|l|l|}
\hline Political sphere & \\
\hline & civic sphere (y) \\
\hline & \\
\hline
\end{tabular}

symbolic/mediated

\section{Methods}

To understand the concept of citizenship and the role of social media in the development of the movement, I used a qualitative case study approach. Case study approach offers description of research using inductive investigation in a holistic way to exemplify the phenomenon and understand the multifaceted situation of the subject (Rossman \& Ralls, 1998). I collect the archival data consist of messages posted in the Facebook group of Indonesian movements, and its evolution until it becomes a political party.

The methods allow researcher to find important artifacts such as people opinions, conversations, and their personal expression (Richardson, 2003). The comment artifacts from Facebook members will emerge the pattern of opinions, expressions, content productions, and organization virtual activities. ${ }^{1}$

The outcome of the data analysis, which is interpretation on meanings, ideas, and value, will be useful to support other research and sample through this typological description. I used three Facebook Group according to the movement evolution to take the appealing, distinctive, essential, and typical comments. I start in August 1, 2011, through October 1, 2011. Roughly I take 50 main posting messages per Facebook Group during that period for further review and analysis (In total I collect 150 main posting messages, thus I collect 446 messages include the

${ }^{1}$ The names that appear in the comments are the fake names of Facebook members to protect the confidentiality. The names (organizations and individuals), which appear in the comments of Facebook members, are hidden using special marks to protect their image and reputation if they get negative comments. 
response towards the main postings). The results of the interpretation revealed five categories on Facebook roles in the development of the movement. Finally, I re-examined the sample of the data (The latest 100 main posting comments per Facebook Group, using backward time from October 1, 2011) to calculate the estimation frequency of the five categories of Facebook role in the movements (In total, I re-examined 300 main posting messages).

\section{Result: 'Click’ Action to Political Party}

\section{Facebook Group "We Believe in the Integrity of Sri Mulyani Indrawati”}

The Facebook Group started gaining support in the end of 2010 after the issue of Century Bank brought the name of Sri Mulyani Indrawati in the House of Representative judgment. Sri Mulyani was the coordinator of the team to decide whether or not the government needed to give bail out to Century Bank in 2007. In 2009, when Sri Mulyani became the finance minister of Indonesia, the House of Representative started to question the decision of giving bail out to Century Bank. The members of parliaments questioned the legitimation, procedure, and the system of bail out. In the television such as TV One and Metro TV, people could watch dozens of parliament members judged Sri Mulyani as the one who should be responsible for creating disadvantage to the country by giving bail out to a bankrupt bank for 746 million dollar US. Thus, during the process of interrogation, the Facebook supporters for Sri Mulyani started to appear. The supporters press the "like" button in the Facebook Group and give comment about the issue on the Facebook wall.

Public participation on the Facebook Group "We believe in the Integrity of Sri Mulyani Indrawati" reached over 131,000 members in only one and half month. This number of people is only $0.3 \%$ of Facebook users population in Indonesia which now up to 31,784,080 Users (Socialbakers.com, 2010) or only $0.05 \%$ of total population in Indonesia. However, this public support reached more than 100.429 members in just a month according to Detik.com (Wednesday, 24/02/10). This Facebook group became a public advocacy from the members to Sri Mulyani as an individual in political problem.

From the case above, I argue that the Facebook Group to support SMI goes characterized in mediated and civic ends of the continua. The reason is because (1) this Facebook movement mainly use mediated communication system, to express their opinion and engage in public advocacy as civic practice (2) This movement concerns to support 
individual, not to change a political system or policy. The civic engagement on a public advocacy exists to support the democratic participation. The research also suggests that the Facebook supporter group tend to be a "virtual" action than a "real" action, due to the high intensity of virtual conversation.

\section{SMI-Keadilan (Solidarity of Indonesian Sociaty for Justice) Movement}

The group support continued further by building the social movement of SMI Keadilan (Solidaritas Masyarakat Indonesia untuk Keadilan) or SMI Justice (Solidarity of Indonesian Society for Justice). It is also the abbreviation of the inspired figure of this movement, Sri Mulyani Indrawati (SMI). The social movement uses social media mainly to mobilize their activities in every province. Their activities include (a) create declaration event by inviting online members or other people who interested to support Sri Mulyani (Rosemarie, 2011) (b) Small meeting for the committee to coordinate the event and disseminate information about the movement of SMI Keadilan per province. Thus, they utilize Facebook with the name of SMI Keadilan and the province name, such as SMI Keadilan Jakarta Province, SMI Keadilan Yogyakarta Province, SMI Keadilan East Java Province, and many other provinces.

The movement existed per province and had own their own base camp, leaders, and activities. Before going further, I would like to address the definition of social movement, to indicate the relevant of the case study with the conversation on social movement. Diani (1992) defined social movement as "networks of informal interaction between a plurality of individuals, groups and/or organizations, engaged in a political or cultural conflict on the basis of a shared collective identity" (p. 13). Thus, SMI-K Movement, could be define as a social movement since it consists of interaction between various individual, and share the same identity as the supporter of Sri Mulyani. In the case of SRI Party and SMI Keadilan Facebook Group or movement, the social media become the database for the party to organize their members for the verification process (Ward, 2011). I also argue that SMI Keadilan is a "real" movement which majorly using the combination of virtual connection and real connection to facilitate their interaction.

\section{SRI Party}

The next phase after Facebook group in provincial-based, they have the intention to build political party. The objective is to support their inspired figure to enter 
the presidential candidacy in 2014. The requirement to be a candidate of the president is each candidate should have a political party to bring his or her name in the presidential election. According to the constitution or UU Number two the year of 2008 about the requirement to build political party, every political party must have representative in minimum $75 \%$ regency, in every province, and 50\% sub-district, in every regency. The founders of the party should also consist of 30 people in every province and 10 people in the central government or Jakarta (Pemiluindonesia.com). They need to go through the verification phase to make them registered as a political party. This movement started from 'like' and now are a political party called SRI (Serikat Rakyat Independent or Union of Independent People), the name of Sri Mulyani Indrawati also inspired the party's name.

The Party was established in May 2nd, 2011 and registered their name in Ministry of Law and Human Right Republic of Indonesia in August 3rd, 2011. The party's movement used publication through conventional mass media, digital media, face to face, small/large group meeting. However, until 27 November 2011, the members of SRI Party in their official Facebook are still around 753 members. The goal of a political party is clear, that it will be aimed to outreach the political sphere for political purpose. The activities of this party will augment support of their constituents as political participation by collecting the signature and copy ID of members (for verification) and community or cultural engagement such as giving 'qurban' (animal) in Islamic celebration (Cakrawala News, 2011). They also unfolded a meetingin The House of Integrity or branch office (Republika, 2011) and produce press releases or press conferences, websites, and news update for political publication (Detik, 2011). Thus, I argue that the political party goes to the pole of the political sphere. I also argue that political party could be "real" action, which is supported by virtual media but concern majorly to political membership, engage in political action such as campaign, voting, and actions.

On the map we could see that the movement have tendency to go further to political sphere. I argue that political sphere has become one of the solutions to gain their objective and social media has become the main way to organize the movement. Therefore, here is the map of 'All about Sri' Movement 
Graphic. 1.2. Mapping of "SRI Movement"

Face to face (x)

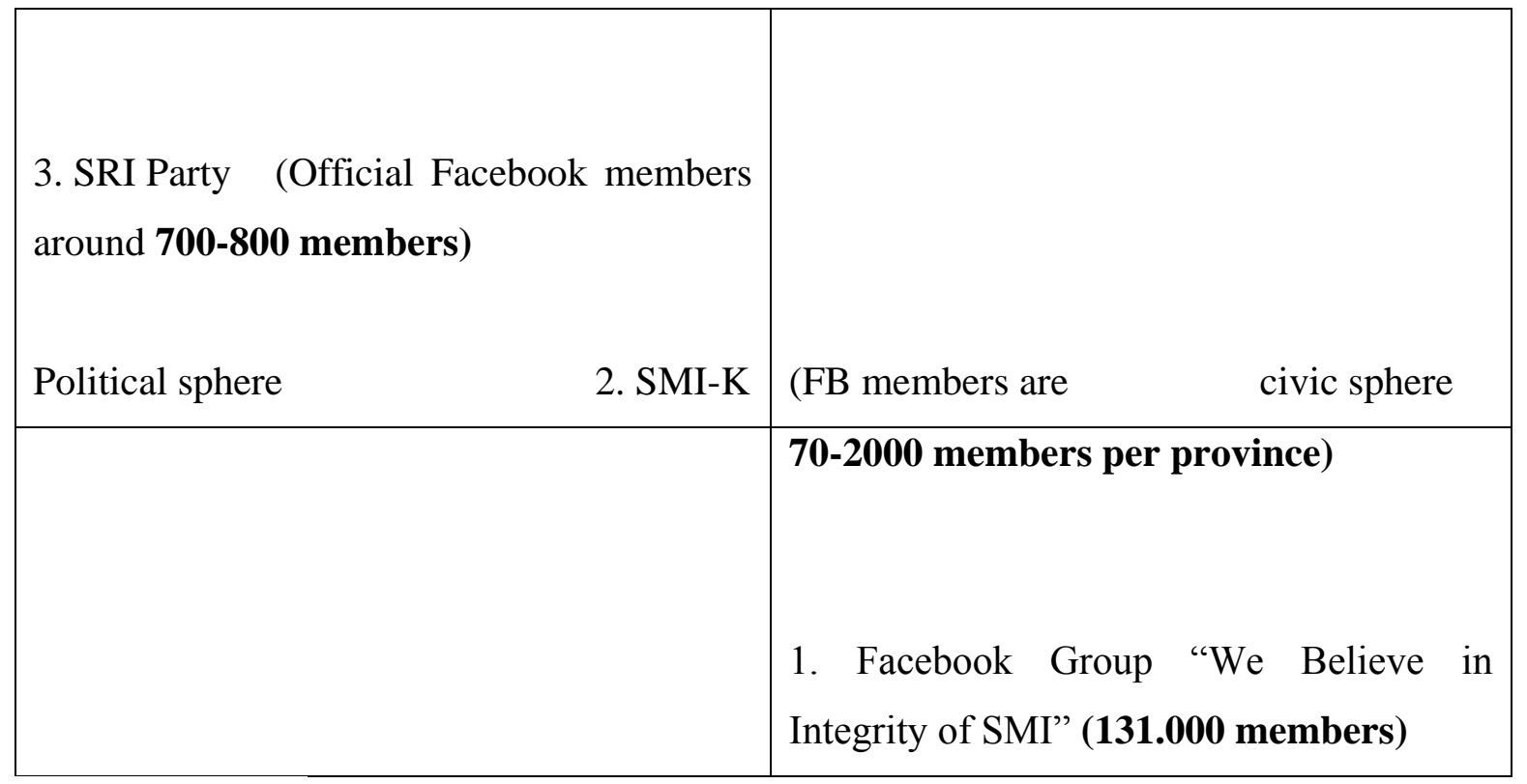

symbolic/mediated

According to the map, the movement was evolved from virtual- based action to real-based action and from civic sphere to political sphere. The map illustrated the changing sphere and dynamics of movements. The interchange process happened because of the alteration of movements objective, which start from civic objective to advocate individual in political problem, to political objective to create political party, represent society in house of representative, and ultimately bring their main figure as president.

The communication mode is also changed. In the beginning, the movement use mediated communication for most of the time. The movement engages the members through Facebook, and it becomes the dominant way to communicate with unorganized members and geographically spread out throughout the country. As the time passed, the movement changes to combine more mass media usage and other communication mode, such as group meeting, organizational communication, and public communication in the provincial level. The social movements sets various activities to meet and communicate with the members based on geographic area. The political party engages more in organizational communication by creating formal meeting (direct or face to face communication between members) and structures. Similar with the argument from Breese (2011), that the movements are not static objects. The movements move along the axes. Breese says, "Public sphere that begin as civic 
public spheres may become political and political public spheres may become more civic in their practice and orientation"(2011, p. 141).

\section{Five Categories of Facebook Roles}

Five categories of Facebook role associated in the movements such as: public defense, political support, presidential allegiance, creative manufacturing, and counter disturbia.

Public defense refers to Facebook Group's function to express personal opinion to defend or advocate for another individual, especially to support Sri Mulyani in the Century Bank issues. Message in this category appear to persuade, prove point using personal argumentation or expert (by posting the link of expert analysis), identify individual whom they support as marginalized, identify institution or other individual in politic as rivals or "antagonist" figure who put pressure to their supported figure, and identify issue by posting digital mass media link. About $15 \%$ of the posting samples in SRI Party, $21 \%$ in SMI-K Jakarta, and $42 \%$ in "We Believe in Integrity SMI" Facebook Group were considered as advocacy to individual category.

Political Support refers to Facebook Group's function to inform members about regional and national issue/news related to their political party and to organize 'real' action under the umbrella of political party in national or regional scope. About $26 \%$ of the posting samples in SRI Party Facebook, 26\% in SMI-K Jakarta Group, and 4\% in "We Believe in Integrity of SMI" Facebook Group, were considered as support statement, opinion, and coordination related to political party.

Presidential Allegiance refers to the function of the group to support their figure (Sri Mulyani) in the 2014 presidential elections. Other forms of support are invitation for members to join the virtual voting in other sites or groups, and information on their figure competency, achievements, and positive news. About $39 \%$ of the posting sample in SRI Party Facebook, $10 \%$ in SMI-K Group, and 25\% in "We Believe in Integrity of SMI" group, were considered as support statement for presidential election.

Creative Manufacturing refers to the posting related to personal creative expression (such as personal narration, poems, rhymes, and other art productions). About $18 \%$ of the posting 
samples in SRI Party Facebook, 25\% in SMI-K Jakarta Group, and 23\% in "We Believe in Integrity of SMI" Facebook Group, were considered as creative content production.

Counter Disturbia refers to the posting related to disturbance factors in the group, either from internal or external disturbance. This category included any actions, comments, or people that are considered as disturbing factors towards the Facebook Group. For example the existence of fake members, hackers, and other negative situations especially in politics outside/inside the group. Even though the percentage is minor for example in SRI Party only $2 \%$ postings, while in SMI K Jakarta Group there are 18\% postings, and 6\% in "We Believe the Integrity of SMI", but this category frequently appear as an important information and concerns.

However, in SRI Party Facebook Group, I found the main posting majorly conducted by the organization instead of members. Approximately $98 \%$ of the main postings are from the organization. The members tend to comment on the main post, instead of posting their own production. While in SMI-K Group (Jakarta) and "We Believe in Integrity of SMI", I found diverse posting from diverse members, admin as the gatekeeper of the group also posted information, but many members post their own opinions, creative content, links, etc.

In the following sections, I provide qualitative descriptions and examples from each of the five categories of Facebook role in Indonesian case study. ${ }^{2}$

\section{Public Defense}

The moment when the media still highlighted the Century Bank, which brought the name of Sri Mulyani, many Facebook members express their opinion especially in the "We Believe in the Integrity of SMI" Group.

EGH: "After I watch TV, I support Mrs. Sri Mulyani, just face those stupid parliament members"

HUJ: "All members... I cannot see directly when SMI have a public hearing with The Special Committee of Century Bank Case in Parliament (Pansus Century), but

\footnotetext{
${ }^{2}$ Quotations from the Facebook members are translated by the researcher from Indonesian language to English, and as similar as possible to follow the closest expression in Indonesian version.
} 
I have read all the comments from all of you ... Alhamdulilah (Thank God), O Allah, you gave us ministry who has dignity"

The support statements, which indicate the advocacy to individual, can vary. Activity to support political figure could be included in civic activities (Smith, Schlozan, Verba, \& Brady, 2009). However, the discussion could be high-level as well. For example some visitors provide argumentations to support the stance of Sri Mulyani Indrawati (SMI) and also the rebuttals towards House of Representative statements or questions. The statement above, only show the support statement and more like an expression of individual towards the individual, issue, or the house of representative members. Individuals also indicate that they have emotional appeal regardless they get direct television exposure. Looking at this matter, we can discern, according to Bennett (2008), Self-Actualization Citizen (AC) rooted in selfactualization through social expression.

Public discussion towards the political and national discourse in this Group has multitude topics. The favorite topics that appear in "We Believe in the Integrity of SMI" are the house of representative attitude in judging SMI, the achievement of SMI in answering the questions, the prediction of "who is behind the issue" or "political conspirator" assumption behind Century Case, the media bias towards the issue (some members accused one television station to be biased because it is owned by Indonesian tycoon, who have problem with Sri Mulyani previously), political party who defend or oppose SMI, and the statements from other political figures. Thus, in this dynamic of public discussion, they were in attempt to advocate SMI by providing the oppressors and the marginalized. It is obvious to get the information from Facebook members to find who is the figure that they perceived as oppressors. These postings resurfaced in "We Believe in the Integrity of SMI."

OCS: "She did all the things she has said (INTEGRITY)... Even though, the house of parliaments screams to her and slaps the table in front of her, she faced maturely so that she looks calm and unmovable".

OB: "It was terribly naive when our people let the leaders ...were subjected to unreasonable judgment and eventually will lead to character assassination..." 
HL: $\quad \mathrm{M}^{* * * *}$ TV reporter just said that we have 95 members, Woooiiii... We have 95 THOUSAND! Mistake or "mistake"? Check this link."

GS: "ck ck ck... TV O**, come on! I know your owner (Ic*l) ask you to say that, such a biased TV"

HD: "With the new position as World Bank Managing Director, it is proven that SMI has integrity and very smart. Only the chosen people can have that position. Indonesia has thrown away the intellectual people to other country, we get nothing"

IJ: "Yellow party give maneuver, blue party answer it not in elegant way with $\mathrm{Lu}^{* * t} \mathrm{Sit}^{* * * *}$ as the speakers, Gus Dur (the forth President of Indonesia) is right, House of representative is like kindergarten!"

Recognizing that the Facebook members inform the antagonist and protagonist figure in the issue, illustrates the assumption of Samuel (2007) on public advocacy. He maintained that public want to question the power relation they perceived especially through the conventional media portrayal. Most of the Facebook members have positive 'response' towards SMI and her answers; perceive her as marginalized individual in politics, and engage through conversational forms with other members. As Wooley (2010) argued that Facebook can counter the dominant discourse in conventional agenda setting media. Here, the Facebook Group demonstrates that the members noticed the biased information from conventional media, and use Facebook to express their disappointment and contradictory opinion. Thus, Facebook become alternative information for members and "fighting" strategy against the dominant discourse in politic and conventional media setting.

\section{Political Support}

The Facebook members also give comments on political party as a "vehicle" to bring Sri Mulyani to presidential candidacy. They discuss the idea of political party requirement in Indonesian pre-existing democratic system. They also discuss solidarity movements, which is the SMI-Keadilan movements, as a solidarity group to Sri Mulyani.

KK: "We need to prove ... that SMI was not engaged in the corruption in Bank Century case.... they are flipping the facts and legal law... We must clean her name with our MAGICBROOM". 
HJ: "Congratulation for the first launching of House of Integrity"

FG: "SRI Party is formed by the activist of Solidarity of Indonesian Society for Justice (SMI-K) who support Sri Mulyani. The important figure and activist who initiate the party are those who never been in the practice of politic"

Another interesting point is they also use the Facebook Group to organize 'real' action under the umbrella of political party or solidarity movement in national and regional scope. Activities such as announce, invite, and report members about the events also exist to support the political party.

RE: "In a few days ahead, nearly 3 million membership form will be sent to the Provincial representative of Party SRI. Friends, who want to come fill out the form for personal, family and colleagues, please contact one of the closest party officials"

YU: "Please come to our declaration of SMI-K Yogyakarta Province... we have discussion about public ethics and declaration ceremony for the regional committee"

HG: "Our meeting with Wimar Witoelar" (shows photo of the activities)

The Facebook members also use the group to discuss political situation in regional and national context, whether it is related to Sri Mulyani case or not. The Facebook become an arena for public political discourse.

\section{Presidential Allegiance}

The support towards SMI to be the next candidate in Presidential election in 2014 appeared especially at the end of the House of representative judgment. Sri Mulyani chose to resign from her position as Finance Ministry of Indonesia and accepted the offer from World Bank to work as the managing director in Washington D.C. At this point, the discussion refers to her candidacy as President.

AH: "Welcome back RI 1 in 2014"

SY: "So sad to say goodbye to you, SMI, but please come back in 2014, we need you. SMI for president" 
Another attractive content in Facebook Group is the positive portrayal of Sri Mulyani as their “political celebrity". There are many postings, comments, or link, which refers to 'glorify' the achievements of Sri Mulyani, in the past (when she still become Indonesian Minister), positive prediction upon her candidacy, and the present news about Sri Mulyani. Here are some examples.

GC: "Virtual polling... Sri Mulyani get the second position, Let's join the voting!" Response:

DC: "Who want to choose I*** whose hands full of Lapindo Mud? Who want to choose $\mathrm{T}^{* * *}$ whose hands proven as murder of a judge? Sri Mulyani is my choice. Smart, Integrity, honest, and make Indonesian proud with her International achievements"

VV: "She was one of the influential women in Forbes Magazine, and still now"

GD: "I lie if I say I*** is not afraid of Sri Mulyani if she run for Presidential candidacy"

YG: "Sri Mulyani stays silent when the media ask about her candidacy as President in 2014. It is part of her ethical profession and integrity in her position as World Bank Director"

These sample postings illustrated the conversational sphere among members about the presidential candidacy. In the Facebook Group, individuals can express various information about their like/dislike opinion towards issue to presidential candidate. Tanis and Postmes (2003) mentioned this freedom as an instrument to facilitate presidential elections and provide additional information towards the candidate.

\section{Creative Manufacturing}

Some members in Facebook create various creative or artistic productions to show their involvements in the issue or just to entertain other members. Creative content production has significant percentage because it is the expression of individual. Kay and Johnson (2002) determined the entertainment factors as one of the reason why people use media for political information. Thus, political information could be entertaining. 
UU: "Look what our house of representative do when they get salary from us. Snoring!" (Picture showed the parliament members sleeping in the meeting room).

ST: (poems) "When you become the opponent of stinky-rubbish politicians, there is no political power to protect you. But believe me the people will have sympathy to you and defend you. Even though the support is spread out, without institution, and weak in political power. But social support exist to erase your tears"

GG: "Black and White, you will see the battle between Sri Mulyani and I*** in 2014, because people will know which one is white and black!"

\section{Counter Disturbia}

The group found some internal problems connected with the existence of fake account, hacker, and fake members who disadvantage other members or people outside the group. Here are the examples:

RS: "Be careful to the fake accounts of ER and SR. There are many attacks to SMI$\mathrm{K}$ and SRI Party. Why they want to attack? It is because they do not like us. Who? You know who!

RT: "Anybody know these account names? ... Be careful with this account. It is hijacked and perhaps fake"

FF: "Do not add DS account as a friend, because it is fake. Look at the mutual friends"

TY: "This name YY is fake members and has collected ID cards under the name of SRI Party, please inform more about this individual"

GH (admin): "I have deleted the YG name as a member. Please inform me any fake members and fake account"

Other negative presumption in keyboard activism is the issue of security. The easy access to be a member in Facebook group make it easier for "strangers" or those who included as the opponent of the group to enter the group with fake identity, hacking account of Facebook members, create opposition debate, use the group name to create "real" activism which deceive the people outside virtual media, such as by collecting ID Card in SRI Case, and 
posting their own interest or business (create 'junk' posting such as commercials, porn, games applications, which will disturb the members of Facebook Group). The functions of admin to be the gatekeeper to unregister the "disturber," while members coordinate and discuss the internal issues through the groups.

\section{Discussion}

There are two dynamics according to the development of this movement, which are the dynamics of citizenship and media. The dutiful citizenship has developed as the longestrunning citizenship paradigm for the last century, thus DC appear first before AC (Schudson, 1998). While, the idea of Self Actualization Citizen is a new forms of citizenship to response the development of digital media, and accessibility to the public (Bennett, 2008).

However, if a virtual-based movement is directed to participate in political sphere, especially in formalized system, then the movement has to evolve back from AC to DC. It means that the idea of non-conventional citizenship has to convert to conventional citizenship (Ward, 2011). Thus, the concept of personal interest through the virtual network will probably decline, due to the organizational/party's democratic agenda, which has been established and maintained by the "powerful" or "authority" individuals within the party. The Facebook of SRI Party, which has shown that the authority to post information has fallen to organization (SRI Party), through the dominant main posting. I argue that the interactivity, discussion, and informative form will still be performed in the Party's Facebook Group but the domination of source of information will be in the hand of organization. Thus, the political party (SRI Party) shows organizational dominant move, while the social movements (SMI K and "We Believe in the Integrity of SMI") shows members move. However, I still agree to Norris (2003) that the interactive linkage between party and members still exist in this particular case.

The interesting point from the map is the decreasing amount of Facebook members. The SRI Party did not gain membership in Facebook as fast and as many as "We believe in the integrity of SMI". Even though, SRI Party is still new; however, it leads to the question of Earl and Shussman (2003) which is about the 'members' convert to 'users' and the tendency that people tend to disengage after the action they support in digital media develop further. This situation challenges the commitment of members, since virtual members have weak-tie bonding (Kavanaugh et al, 2005). The political party, which previously was social movement 
and get hundred thousand members in only one month, have to find support in "real" action, "real" commitment, and play with "real" number of members through established democratic system. I argue that the conditions will require double burdens. First, when the political party has to reach wider public through conventional media, it will increase their transactional cost. Not to mention the time and energy to overcome the typical cultural challenge in incumbent democratic participation. Second, the political party also has to get "real" commitment and trust from public to reach their main objectives. They need to prove that the commitment in virtual media can be manifested in the incumbent democratic system

Result of this research suggested that Facebook has facilitated the 'conversational sphere' in citizenship discourse and political discourse in five categories. Public defense provide opportunity for Facebook members to express their perception on the power relation issue in politics. Political support category provides information on how members organize real actions to manifest their virtual support. Facebook is also bridging connection to coordinate members in 'real' actions through the activity of inviting, announcing, and reporting to members. While the presidential allegiance provide information regarding to specific person. Another interesting point is through this category, the personae of candidate in members' perception are appeared in public. Members can show their opinion towards the attitude, achievements, and carrier development of candidate.

Creative content production illustrates the freedom of expression and individual empowerment to publicly provide individual stance towards political issue and presidential candidate based on their creativity. Finally, the conversational topic on counter the disturbia can be another negative point in social media engagement especially in political discourse. The accessibility of Facebook to register without strict validation system can make any individual create disadvantage situation to other members or general public. The security issue in Facebook Group is only depending on the admin as the gatekeeper to decide who are eligible as members. Call for research upon the disturbance factors in social media towards political organization, with special focus on virtual context or reality context as the disturbance manifestation is necessary. The important point of further research is to understand the dynamics of organization stability and individual security in virtual group membership. 


\section{References}

Bennett, W. L. (2008). Changing Citizenship in the Digital Age. Civic Life Online: Learning How Digital Media Can Engage Youth, ed. W. Lance Bennett (pp. 1-24). Cambridge: The MIT Press.

Business Monitor International, Ltd. (2011). Indonesian Political Outlook. Indonesia Business Forecast Report; 2011 4th Quarter, Issue 4, p7-11, 5p, 2 Charts. Retrieved from: http://web.ebscohost.com/ehost/pdfviewer/pdfviewer?sid=f6b4973f-e9e2-4559-abb725072a6000f2\%40sessionmgr4\&vid=1\&hid=12

Breese, E. B. (2011). Mapping the Variety of Public Spheres. Communication Theory, 21, 130-149.

Byrnes, S. (2011). After the Dictactor: Want to know what will happen in the Arab world after the fall of despots such as Gaddafi and Mubarak? The place to look is Asia. New Statesman; 9/12/2011, Vol. 140 (5070), 29-33

Coleman, S. \& Blumler, J. (2009) The Internet and Democratic Citizenship: Theory, Practice and Policy. Cambridge: Cambridge University Press

Dahlberg, Lincoln. (2001). Extending the public sphere through cyberspace: The case of Minnesota E-democracy. Retrieved from: http://www.uic.edu/htbin/cgiwrap/bin/ojs/index.php/fm/article/view/838/747

Dahlgren, P. (2009) Media and Political Engagement: Citizens, Communication and Democracy. Cambridge: Cambridge University Press

Dakroury, A. and Birdsall, W. ( 2008). 'Blogs and the Right to Communicate: Towards Creating a Space-Less Public Sphere?', The International Symposium on Technology and Society Proceedings. Fredericton, New Brunswick: Institute of Electrical and Electronics Engineers.

Detik.com. (2010, February, 27). Dukungan Facebooker kepada Sri Mulyani Menembus 100.000 Anggota (Support of Facebooker to Sri Mulyani reach up to 100.000). Retrieved from: http://forum.detik.com/dukungan-facebooker-kepada-sri-mulyanimenembus-100-000-anggota-t146058.html

Diani, M. (1992) 'The concept of social movement', Sociological Review, vol. 40 (1), 1-25.

Diani, M. (2000) 'Social movement networks. Virtual and real', Information, Communication \& Society, vol. 3(3), 386-401.

Earl, J. \& Schussman, A. (2003) 'The new site of activism: on-line organizations, movement entrepreneurs, and the changing location of social movement decision-making', in 
Consensus Decision Making, Northern Ireland and Indigenous Movements, ed. P. G. Coy (pp. 155-187). London: JAI Press

Gibson, R., Ward, S. \& Nixon, P. (2003) Political Parties and the Internet: Net Gain? London: Routledge

Jakarta Globe. (2010, January 10). Indonesia now Home for $6^{\text {th }}$ Twitter Users in The World. Retrieved from: http://www.thejakartaglobe.com/home/indonesia-now-home-to-6thmost-twitter-users-in-world/352871

Kann, E. Berry, J. Gant, C. and Zager, P. (2007). The Internet and Youth Political Participation. First Monday Journal, 12. Retrieved from: http://firstmonday.org/article/view/1977/1852

Kavanaugh, A., Reese, D. D., Carroll, J. M. \& Rosson, M. B. (2005) 'Weak ties in networked communities', Information Society, 21 (2), 119-131

Loader, B \& Mercea, D. (2011). Networking Democracy? Information, Communication \& Society, 14:6, 757-769

Meikle, G. (2002) Future Active: Media Activism and the Internet. New York: Routledge

McCombs, M. E. (2004). Setting the agenda: The mass media and public opinion. Cambridge, UK: Blackwell Polity Press

Negroponte, N. (1996). Being Digital. New York: Vintage Books

Norris, P. (2003) 'Preaching to the converted? Pluralism, participation and party websites'. Party Politics, 9(1), 21-45

Pemiluindonesia.com. (2008, January 4). UU No 2 Tahun 2008 Tentang Partai Politik (Constitution Number 2 year of 2008 About Political Party). Retrieved from: http://www.pemiluindonesia.com/undang-undang/undang-undang-no-2-tahun-2008tentang-partai-politik.html

Pringle, R. (2011). Indonesia's Moment. Wilson Quarterly, 35 (1), 26-33. Retrieved from: http://0search.ebscohost.com.catalog.library.colostate.edu/login.aspx?direct=true\&Aut hType= cookie, ip, url, cpid $\&$ custid $=s 4640792 \& d b=a c h \& A N=B A R T 11105852 \&$ site $=e h$ ost-live

Richardson, J.D. (2003): Uses and Gratifications of Agnostic Refuge: Case Study of a Skeptical Online Congregation, Journal of Media and Religion, 2:4, 237-250. Retrieved from : http://dx.doi.org/10.1207/S15328415JMR0204_2

Rossman, G. B., \& Ralls, S. F. (1998). Learning in the field: An introduction to qualitative research. Thou- sand Oaks, CA: Sage. 
Rosemarie, E. (2011). Malang, Banten, Sumatera Selatan dan DI Yogyakarta Bergabung Dalam Gerakan SMI-Keadilan. Press Release. 04/PR/SMI-K/VI/2011. Retrieved from: http://srimulyani.net/2011/06/28/press-release

Samuel, John. (2007). Public Advocacy and People Centered Advocacy: Mobilizing for Social Change, 17(4-5). New York: Taylor and Francis Group

Schudson, M., (1998). The good citizen: A history of American Civic Life. New York: The Free Press.

SMI Keadilan. (2011, June 27). Mission of SMI Keadilan. Retrieved from: http://www.smikeadilan.org/2011/06/visi-dan-misi-solidaritas-masyarakat_27.html

Smith, Schlozman, Verba, Brady. (2009). The Internet and Civic Engagement. Pew Internet. Retrieved from: http://pewinternet.org/Reports/2009/15--The-Internet-and-CivicEngagement/1--Summary-of-Findings.aspx

Socialbarkers. Com. (2011, January 27). The Fastest Growing Countries on Facebook in 2010. Retrieved from: http://www.socialbakers.com/blog/106-fastest-growingcountries-on-facebook-in-2010/

Tanis, M., \& Postmes, T. (2003). Social cues and impression formation in CMC. Journal of Communication, 53, 676-693.

Ward, J. (2011). Reaching Citizen Online. Information, Communication \& Society, 14(6), 917-936

Wooley, J. K. Limperos, A. M, Oliver, M. B. (2010). The 2008 Presidential Election, 2.0: A Content Analysis of User-Generated Political Facebook Groups. Mass Communication and Society, 13, 631-652, doi: 10.1080/15205436.2010.516864

World Bank. (2011). Indonesia. Retrieved from: http://data.worldbank.org/country/indonesia

Xenos, M. \& Foot, K. (2008) 'Not your father's internet: the generation gap in online politics', in Civic Life Online: Learning How Digital Media Can Engage Youth, ed. W. L. Bennett, The MIT Press, Cambridge, MA, pp. 51-70.

Young, I. M. (2000) Inclusion and Democracy. Oxford: Oxford University Press 